\title{
How Familial Cancer Genes and Environmentally Induced Oncogenes Have Changed the Endocrine Landscape
}

\author{
Sylvia L. Asa, M.D., Ph.D. \\ Pathologist-in-Chief, University Health Network and Toronto Medical Laboratories, Toronto, Ontario, \\ Canada
}

\begin{abstract}
The gene responsible for $\mathrm{MEN}-2$, the ret protoocogene, has elucidated mechanisms of endocrine tumorigenesis. Activating mutations of this transmembrane tyrosine kinase receptor represent the first known example of an inherited oncogene. This knowledge has altered our approach to affected patients by allowing in utero screening and prophylactic thyroidectomy rather than provocative testing and morphologic analysis of $\mathrm{C}$ cell hyperplasiawill it result in eradication of medullary carcinoma of thyroid? The lessons from Chernobyl taught us how radiation can induce chromosomal rearrangements that involve the same gene. This has led to a better understanding of papillary thyroid carcinoma and provides a novel immunohistochemical marker that widens our diagnostic armamentarium.
\end{abstract}

KEY WORDS: Thyroid, Ret proto-oncogene, Medullary carcinoma, Ret rearrangements, Papillary thyroid carcinoma.

Mod Pathol 2001;14(3):246-253

Molecular biology has had a significant impact on the practice of endocrine pathology. This article will focus on various genetic alterations involving a single gene and a single tissue to illustrate the "benchto-bedside" application of molecular diagnostics.

\section{Medullary Thyroid Carcinoma is Frequently a Familial Disorder}

Medullary thyroid carcinoma (MTC) may have a familial predisposition that falls into one of three types: familial medullary thyroid carcinoma alone (FMTC), multiple endocrine neoplasia (MEN) type

Copyright () 2001 by The United States and Canadian Academy of Pathology, Inc.

VOL. 14, NO. 3, P. 246, 2001 Printed in the U.S.A

Date of acceptance: December 12, 2000.

Address reprint requests to: Sylvia L. Asa, M.D., Ph.D., University Health Network and Toronto Medical Laboratories, 610 University Avenue, Toronto, Ontario, Canada M5G-2M9; e-mail: sylvia.asa@uhn.on.ca.
2A in which MTC is associated with pheochromocytomas, and MEN 2B in which the thyroid and adrenal disorders are associated with mucosal ganglioneuromas and a Marfanoid habitus. Identification of carrier status for individuals in families with predisposition is important to prevent the potentially lethal outcome of MTC. Familial MTC is often multicentric and arises from underlying C-cell hyperplasia (1). This led to the use of C-cell hyperplasia to identify familial cases; apparently sporadic tumors can represent index patients, and the protocol for examination of a thyroid with MTC included an evaluation of underlying C-cell hyperplasia. Many definitions of C-cell hyperplasia have been offered, all requiring immunohistochemistry because $C$ cells cannot be reliably recognized with routine histologic stains. Quantitation of $\mathrm{C}$ cells and geographic mapping throughout the gland must be performed $(1,2)$. C cells are usually limited to the junction between the upper and middle thirds of the lateral lobes where they are distributed singly rather than in clusters. Increased numbers of $\mathrm{C}$ cells (more than seven cells per cluster), complete follicles surrounded by $\mathrm{C}$ cells, and distribution of cells beyond this geographic location are indicative of C-cell hyperplasia (Fig. 1). Pathologists devoted many hours to the meticulous morphometric evaluation of calcitonin-stained tissue sections. Inevitably, there were borderline specimens (3). False positive samples also resulted, because C-cell hyperplasia also can be associated with chronic hypercalcemia, follicular nodular disease, and thyroiditis (4-7).

Members of kindreds afflicted by FMTC or MEN-2 were required to undergo repeated testing to determine carrier status. This entailed serum calcitonin measurements and annual pentagastrin stimulation testing to identify early any rise in circulating hormone levels or any abnormal response that would herald the onset of disease. Pathologists were asked to evaluate thyroidectomy specimens to confirm the presence of C-cell hyperplasia in those 


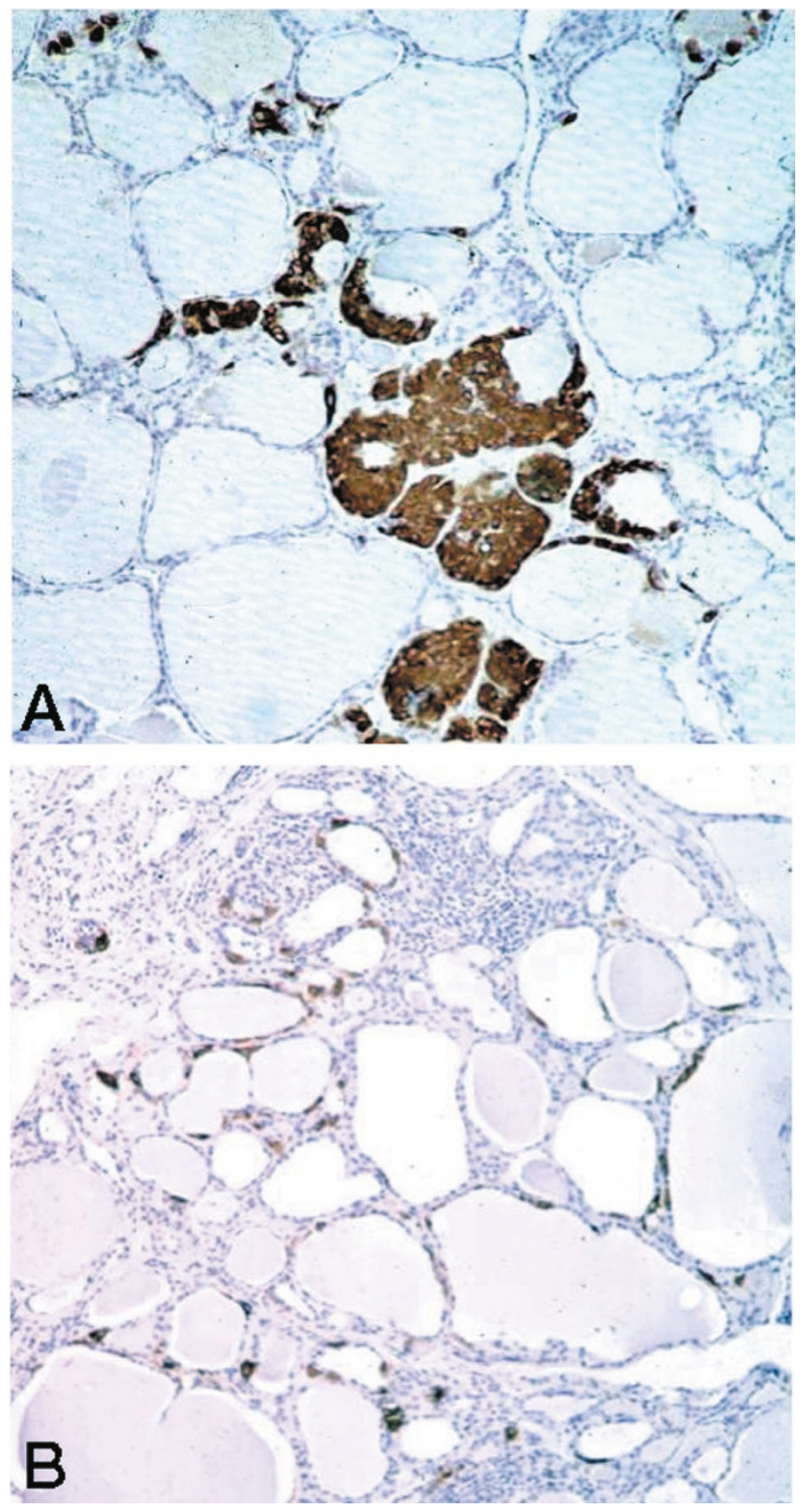

FIGURE 1. A patient with familial medullary carcinoma of thyroid usually has $\mathrm{C}$ cell hyperplasia in the contralateral lobe. A, Sometimes the hyperplastic foci are obvious and the diagnosis of a familial disorder is readily proven. B, In some patients, $C$ cells are numerous, but the criteria for a diagnosis of hyperplasia are difficult to prove.

who had abnormal biochemical tests. Again, the structural features did not always allow unequivocal identification of carriers of the disorder, nor was it possible to provide verification of normal status using this technology. Moreover, there were always examples of patients whose biochemistry only provided evidence after the disease had spread.

\section{Familial MTC and MEN-2 Are Associated with Mutations of the Ret Proto-Oncogene}

Using linkage analysis, the inheritance of all three syndromes was mapped to the pericentromeric region of chromosome $10(8-11)$. The disease exhib- ited an autosomal dominant inheritance pattern with age-related complete penetrance, suggesting inheritance of an activated oncogene. In seemingly unrelated work, a chimeric oncogene was found to induce classical NIH 3T3 transformation; the gene involved on chromosome 10 was named "RET" because it was "REarranged during Transfection" (12). This gene, with 20 exons in over $60 \mathrm{~Kb}$ of genomic DNA, encodes a transmembrane receptor tyrosine kinase (Fig. 2) that has an extracellular ligandbinding domain with homology to the cadherin genes, a cysteine-rich extracellular region that has been implicated in protein conformation and dimerization, and an intacellular split kinase (13). In 1993, mutations of the ret proto-oncogene were shown to segregate with disease inpatients with FMTC or MEN 2A (14) and subsequently with MEN 2B (15-17), confirming the role of this gene in the development of MTC in these familial disorders. Highly specific and characteristic missense mutations in three exons of the ret proto-oncogene inpatients with FMTC or MEN2 $(14,15)$ are present in affected members of families but not in individuals not at risk of the disease. The data indicate that mutations of ret are the underlying cause of FMTC and MEN2, providing the first example of a syndrome of inherited oncogene activation.

The function of ret was not clear and therefore its role in the pathogenesis of this disease remained to be proven. Ret expression was found to be specific to cell lineages derived from neural crest, including migrating neural crest cells, the ventral neural tube, autonomic, enteric and sensory ganglia, and thyroid C cells (18). As expected, ret was expressed in MCT as well as in pheochromocytomas and ganglioneuromas $(18,19)$. This pattern of expression was consistent with the disease patterns, but unexpectedly, ret was also found to be expressed in ureteric bud and kidney (20). A mouse model harboring a disrupted ret gene (ret "knockout" mice, ret -/-) clarified the significance of these expression data;

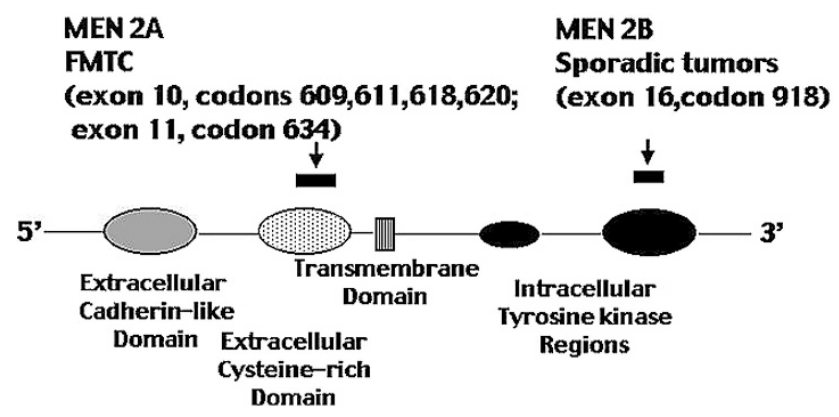

FIGURE 2. Schematic illustration of the ret proto-oncogene and its activating mutations in multiple endocrine neoplasia type 2 (MEN-2) and familial medullary thyroid carcinoma (FMTC). In MEN-2A and FMTC the mutations are usually in the extracellular cysteine-rich region encoded by exons 10 and 11; in MEN 2B there is usually an activating mutation of the kinase domain at codon 918. 
the homozygous animals that lacked functional ret failed to develop an enteric nervous system and kidneys (21). This led to the recognition that inactivating mutations of ret can be implicated in some forms of Hischsprung's disease $(22,23)$.

The structure of ret implicated this protein as a transmembrane receptor, but it remained an orphan receptor with no known ligand until a knockout mouse model deficient in glial-derived neurotrophic factor (GDNF) was found to exhibit a phenotype identical to that of ret $-/-$ mice (21). This led to recognition that GDNF is a ligand for ret $(24,25)$. It is now known that GDNF and ret form a trimeric complex with a GDNF receptor (known as GDNFR $\alpha$ or RETL1) that is membrane-anchored but has no signaling capacity, resulting in signaling through ret $(26,27)$. Another novel cell surface protein, RETL2, has been shown to mediate GDNFdependent ret signaling (28). Thus, inactivation of GDNF or its receptors provide additional mechanisms for the development of Hischsprung's disease.

Patients with FMTC or MEN 2A have highly specific missense mutations in the extracellular cysteine-rich domain of the receptor, mainly in exons 10 and 11; rare examples of mutations in exon 13, 14 and 15 have been described. The most common changes affect five codons for cysteine, codons 609, 611, 618 and 620 in exon 10 and codon 634 in exon 11 Fig. 2). Targeting of these mutant forms of ret to $\mathrm{C}$ cells in transgenic mice results in the development of MTC (29). It has been shown that replacing cysteine with any of several other amino acids increases formation of active ret dimers, explaining the oncogenic potential of these mutations (30). Moreover, patients with MEN 2A mainly have mutations affecting codon 634, and those with a Cys634 to Arg substitution have a greater risk of developing parathyroid disease (31). These data suggest that simple constitutive activation is insufficient to develop a phenotype in tissues other than thyroid $C$ cells, and that tissue-specific factors have an impact on the outcome of ret activation in parathyroid and adrenal. It remains to be shown whether the receptors RETL1 or RETL2 play a role in this mechanism. Moreover, the importance of tissue-specific modifiers is exemplified by the occasional "ret inactivation" phenotype seen in some examples of activating mutations, such as Hirschsprung's disease associated with MEN 2A (32) and renal hypoplasia in mice with MEN 2A activating mutations (33).

In contrast to the wide variety of mutations associated with FMTC and MEN 2A, patients with MEN 2B have a characteristic mutation of codon 918 in exon 16. This genetic alteration replaces a methionine (ATG) with a threonine (ACG) $(15,16)$. This mutation in the kinase region alters the substrate specificity of the kinase, resulting in tyrosine autophosphorylation on new sites as well as phosphorylation of new downstream targets. Activated wildtype ret binds Shc, Grb-2, PLC- $\gamma$ Crk and Nck; in contrast, the mutant form phosphorylates proteins that predominantly bind Crk, Nck, including the cytoskeletal protein Paxillin (34). A number of de novo cases of MEN 2B have been reported with this mutation, and the same mutation is frequent in sporadic MTC $(16,35)$ countering the proposed common ancestral origin theory of this highly specific mutation.

\section{Genetic Screening Is Indicated to Prevent MTC}

Mutational analysis now offers an accurate marker of predisposition to the various diseases (36, 37). The screening approach most widely applied involves direct sequencing of exons 10 and 11 from PCR-amplified products for MEN 2A $(38,39)$ and the simple and more rapid technique of restriction endonuclease digestion for MEN 2B (40). The lethal component of the three syndromes is, indeed, MTC, and prevention of this disorder significantly improves prognosis. Current recommendations suggest that family members of kindreds have genetic screening early in life and affected members should undergo total thyroidectomy at around the age of 5 years (41). This age was chosen because of the early onset of MTC in these familial forms of the disease; metastatic tumor has been found inpatients as young as 6 years of age.

Sporadic medullary carcinomas also may have mutations of ret in the same codons as the familial disorders $(15,42)$; the mutation involved may have prognostic value (43). The presence of ret mutations in sporadic tumors indicates the importance of analyzing DNA from white blood cells to establish that a mutation is not simply somatic but rather involves the germ-line and is therefore potentially hereditary.

In this disorder, unlike other familial cancer syndromes that result from inactivation of tumor suppressor genes, each affected member is born with an activated oncogene. The current trend of using molecular diagnosis to identify carriers of this genetic, autosomal dominant disorder has led to the recommendation of prophylactic thyroidectomy in childhood; this will almost certainly drastically improve the prognosis of the familial forms of this malignancy

\section{Ret is also Implicated in Papillary Thyroid Carcinoma}

The identification of the ret proto-oncogene was rapidly followed by the identification of a novel 
tumor-specific rearrangement of this gene in papillary thyroid carcinoma (44), long before it was recognized as the gene for MEN-2. There are now at least five members of this family of gene rearrangements that are specific to papillary carcinoma. These ret/PTC oncogenes are the result of DNA damage with rearrangements that transpose various cellular genes adjacent to the gene encoding the intracellular tyrosine kinase domain of the ret proto-oncogene (45-50) (Fig. 3). The rearrangements are common in radiation induced tumors (50-54). Ret/PTC-3 has been analyzed to prove the role of radiation in chromosomal breakage and illegitimate recombination (55). Sporadic papillary carcinomas also harbor ret/PTC rearranegements, most commonly ret/PTC-1, followed by ret/PTC-3 and occasionally ret/PTC-2; the etiology of these rearrangements in sporadic papillary carcinomas is not known (56-59).

\section{Ret/PTC Gene Rearrangements Are True Oncogenes}

The tumorigenic role of ret/PTC gene rearrangements was shown using classical NIH 3T3 transformation assays. Moreover, transgenic mouse models have proven the tumorigenicity of these fusion proteins (60-62). However, these animal models have utilized the thyroglobulin gene promoter to drive expression at very high levels.

\section{Mechanisms of Ret/PTC Oncogenesis in Thyroid Follicular Epithelium}

The rearrangements result in translocation of the fusion protein to the cytoplasm and constitutive tyrosine kinase activation (63). Western blotting identifies dimers of ret/PTC-1, providing a mechanism of autophosphorylation and kinase activation,

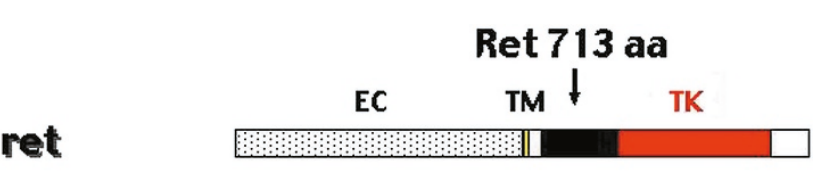

$\mathrm{ret} / \mathrm{PTC}-1$

ret/PTC - 3
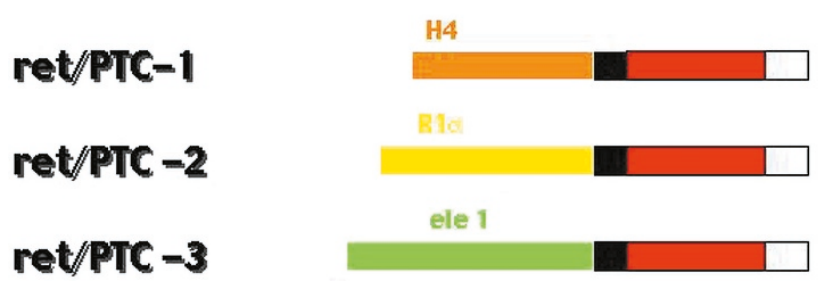

FIGURE 3. The three most common ret/PTC gene rearrangements are shown. The top portion represents the intact ret receptor, with an extracellular region (EC), a transmembrane domain (TM) and a tyrosine kinase domain (TK). The rearrangements involve a breakpoint at amino acid 713 and encode the distal portion of ret including the tyrosine kinase. The upstream portions are regulated by the promoters of other genes, $\mathrm{H} 4, \mathrm{R} 1 \alpha$ and ele, and encode fusion proteins as shown. and the dimerization has been attributed to the leucine zipper region of H4 in ret/PTC-1 (64). Expression of ret/PTC-1 has been shown to impair expression of a differentiated phenotype in a rat thyroid epithelial cell line; this has been attributed to down-regulation of mRNA and protein of the thyroid transcription factor Pax-8 and to altered function of the thyroid transcription factor TTF-1 (65). More importantly, from a diagnostic perspective, ret/PTC-1 alters the nuclear envelope and chromatin structure to account for nuclear features of papillary carcinoma in a ras independent fashion (66).

Ret/PTC-2 involves the Type I $\alpha$ regulatory subunit of cAMP-dependent protein kinase $(\mathrm{RI} \alpha)$. In this rearrangement, dimerization requires the $\mathrm{N}$ terminus of RI $\alpha$ and results in activation sites that bind SH2 domains of PLC $\gamma$ and Grb10; however, these interactions are not required for mitogenesis induced by this rearrangement (67). In contrast, another binding site involving Tyr 586 outside the tyrosine kinase domain interacts with the second of three LIM domains of Enigma and was also identified as a phosphorylation-independent interaction site. Enigma, a 455-residue protein, was discovered because of its interaction with the insulin receptor through its C-terminal LIM domain. The interaction with Enigma has been shown to be responsible for mitogenic signaling by ret/PTC-2.

Ret/PTC Gene Rearrangements in Human Papillary Thyroid Carcinoma

Ret/PTC gene rearrangement appears to be an early event in tumor development, because the rearrangements have been identified with highest prevalence in occult papillary microcarcinomas (68, 69). The data presented above indicate that ret/PTC rearrangements are indeed transforming in vitro and tumorigenic in vivo, but the identification of these gene rearrangements in microscopic carcinomas that are not clinically relevant indicates that they are not potent carcinogens and it is likely that other genetic events are required to promote aggressive tumor growth.

The true incidence of ret/PTC gene rearrangements in clinically significant papillary carcinomas remains controversial and unknown (58), largely because DNA analysis has not proven reproducible and RNA analysis has yielded evidence of variable levels of expression that may require higher sensitivity than previously thought (69). Although early reports identified a frequency of rearrangements as low as $2.5 \%$, most recent reports confirm that ret/ PTC expression is identified in approximately half of these tumors (69). 
Ret/PTC Expression May Be A Prognostic Marker in Papillary Thyroid Carcinoma

These rearrangements have been implicated as predictive of aggressive behavior in pediatric radiation-induced papillary carcinomas after the Chernobyl disaster (70). In patients with radiationinduced solid variant papillary carcinoma, the prevalence of ret/PTC-3 is unusually high, suggesting a possible correlation between this rearrangement and a distinct phenotype (71).

In sporadic papillary carcinomas the levels of expression of the rearranged genes are highly variable (69). It has been suggested that high levels of expression may predict a more aggressive course of lymphatic dissemination (57), specifically in young patients with no other adverse clinical or morphologic parameters (58). The rearrangements are not expressed, however, in the most aggressive papillary carcinomas, such as the tall cell variant or papillary carcinomas with insular dedifferentiation (58). It is therefore recognized that ret/PTC oncogene activation defines a subset of papillary thyroid carcinomas that lack evidence of progression to poorly differentiated or undifferentiated phenotypes $(72,73)$.

\section{Ret Expression Is A Diagnostic Marker in Papillary Thyroid Carcinoma}

Under normal circumstances, ret is expressed in thyroid $\mathrm{C}$ cells and is activated by point mutations in disorders involving $\mathrm{C}$ cells. Ret is not expressed in normal thyroid follicular epithelium. However, when involved in the gene rearrangements known as ret/PTC-1 through -5, that are unique to papillary thyroid carcinoma, the product of the various rearrangements can be identified by immunohistochemical staining for ret (69). The commercial antisera to ret are directed against the carboxy terminus of the protein and this portion of ret is included in the fusion proteins that result from ret/PTC gene rearrangements. Therefore application of this method can identify the expression of a ret/PTC gene rearrangement (Fig. 4). Although RT-PCR for ret/PTC mRNA may be more sensitive, immunostaining is a practical approach to identify tumors that harbor these rearrangements.

Immunohistochemical staining allows rapid and clinically useful detection of this marker of papillary carcinoma, which is present in up to $80 \%$ of occult papillary microcarcinomas and approximately $50 \%$ of clinically detected lesions (69). This genetic alteration provides a marker of papillary carcinoma that has practical application to distinguish borderline lesions that can mimic follicular adenoma. Staining is totally negative in normal follicular epithelial cells. It should be noted, however, that occasional thyroids with Hashimoto's thyroiditis have been reported to harbor
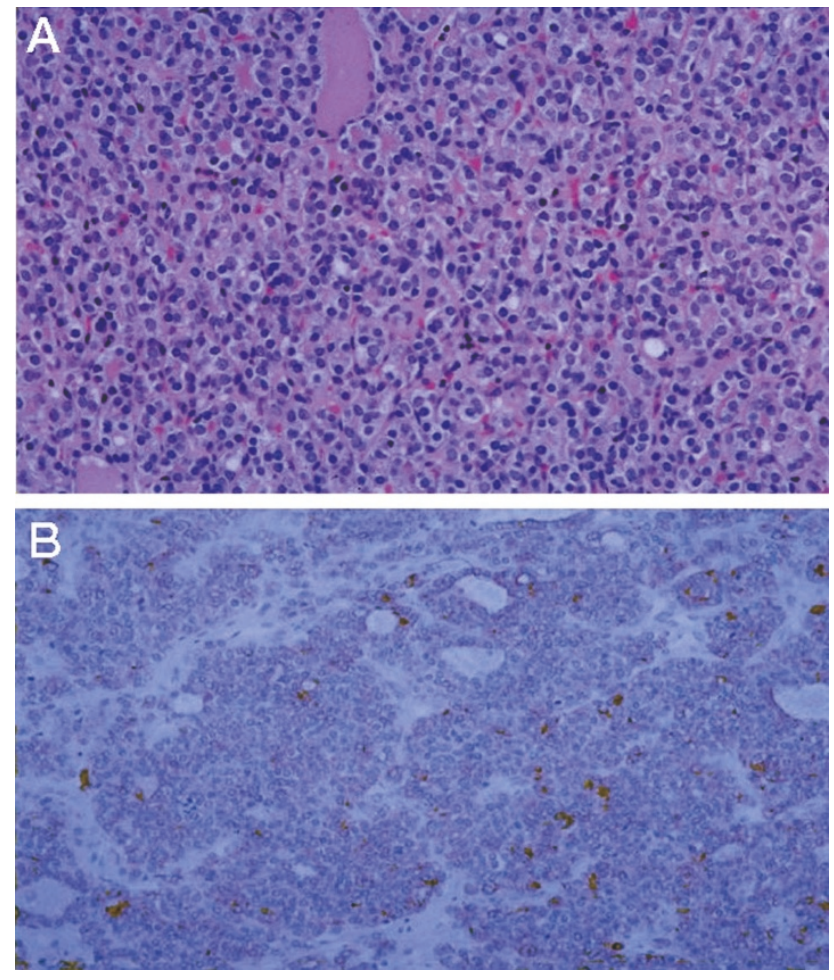

FIGURE 4. The histologic criteria for the diagnosis of papillary can be controversial, as in the tumor shown in (A). Ret immunohistochemistry identifies the $\mathrm{C}$ terminus of the products of ret/PTC gene rearrangements (see Fig. 3) and allows identification of tumors that harbor these molecular markers of papillary carcinoma.

ret/PTC gene rearrangements in the absence of documented malignancy $(69,74)$.

\section{Ret/PTC has Implications for Multifocal Papillary} Thyroid Carcinoma

Papillary carcinomas may be multifocal; this has been interpreted as reflective of intraglandular lymphatic dissemination and has been used as one rationale for total thyroidectomy inpatients with low risk disease. The finding of an occult papillary microcarcinoma in the opposite lobe of a patient with clinical papillary carcinoma may precipitate more aggressive therapy. However, occult papillary microcarcinomas are common in autopsy thyroids and are identified in up to $24 \%$ of the population (75). The opposing view, therefore, holds that these represent incidental findings of no clinical significance. The detection of different ret/PTC rearrangements (e.g., ret/PTC-1 versus ret/PTC-3) in multifocal lesions, even in the majority of patients with clinically significant papillary carcinomas (69), supports the interpretation that these represent multifocal primary lesions rather than intrathyroidal dissemination in most patients.

\section{Ret/PTC has Implications for Hürthle Cell Thyroid Carcinoma}

Hürthle cell tumors are generally classified either as a separate and unique category of thyroid neoplasms 
(76) or as subtypes of follicular lesions $(77,78)$. In either case, they are classified as benign Hürthle cell adenomas or malignant Hürthle cell carcinomas. These two entities are distinguished based on the identification of capsular or vascular invasion or on the presence of metastatic disease (76-78). However, they remain controversial because of their sometimes unexpected behavior $(77,79,80)$.

Several papers have described papillary carcinomas composed of Hürthle cells (81-85). These lesions all have papillary architecture. However, the concept of papillary carcinoma has been expanded to identify well-delineated lesions with follicular architecture and characteristic nuclear features, including elongation, hypochromasia with peripheral margination of chromatin, micronucleoli, and irregular contours with grooves and cytoplasmic pseudoinclusions $(76,78)$. One might expect that there are also Hürthle cell tumors that would be classified as Hürthle cell adenoma but are truly follicular variant papillary carcinomas composed of Hürthle cells; however, the nuclear hyperchromasia of Hürthle cells may mask the features on which the diagnosis would rely. Using ret/PTC gene rearrangements as a marker of papillary differentiation, it has been shown that such tumors do exist and that tumors with ret/PTC gene rearrangements tend to have lymph node metastases (86). This molecular marker is a better predictor of this biologic behavior than morphologic identification of invasion. Therefore the use of ret/PTC as a diagnostic marker supports subclassification of Hürthle cell tumors into three groups: Hürthle cell adenoma, Hürthle cell carcinoma, and Hürthle cell PTC.

\section{CONCLUSION}

The use of molecular diagnostics has changed the endocrine landscape. The Pathologist is seeing less examples of medullary carcinoma as we diagnose familial cases by genetic screening and apply prophylactic thyroidectomy to prevent this disease. We no longer need to analyze thyroids for $\mathrm{C}$ cell hyperplasia to determine whether a patient is a carrier of genetic predisposition.

The applications of molecular diagnostics can make the diagnosis of borderline lesions of thyroid more scientific: tumors with ret/PTC gene rearrangements can be classified as papillary carcinoma if they harbor such a genetic abnormality. This technology will have implications for future diagnosis. This applies to surgical pathology $(87,88)$ and to the preoperative evaluation of thyroid aspirates (89). Moreover, the identification of tumor-specific gene rearrangements may have application to the follow-up care of patients with thyroid cancer.

\section{REFERENCES}

1. Wolfe HJ, Melvin KEW, Cervi-Skinner SJ. C-cell hyperplasia preceding medullary thyroid carcinoma. N Engl J Med 1973; 289:437-41.

2. DeLellis RA, Wolfe HJ. The pathobiology of the human calcitonin (C)-cell: a review. Pathol Annu 1981;16:25-52.

3. Wolfe H, Kaplan M, Cummings T. Reevaluation of histologic criteria for C-cell hyperplasia in MEN 2A using genetic recombinant markers. Henry Ford Hosp Med J 1992;40:312.

4. Albores-Saavedra J, Monforte H, Nadji M, Morales AR. C-cell hyperplasia in thyroid tissue adjacent to follicular cell tumors. Hum Pathol 1988;19:795-9.

5. Biddinger PW, Brennan MF, Rosen PP. Symptomatic C-cell hyperplasia associated with chronic lymphocytic thyroiditis. Am J Surg Pathol 1991;15:599-604.

6. Scopsi L, Di Palma S, Ferrari C, Holst JJ, Rehfeld JF, Rilke F. C-cell hyperplasia accompanying thyroid diseases other than medullary carcinoma: an immunocytochemical study by means of antibodies to calcitonin and somatostatin. Mod Pathol 1991;4:297-304.

7. Libbey NP, Nowakowski KJ, Tucci JR. C-cell hyperplasia of the thyroid in a patient with goitrous hypothyroidism and Hashimoto's thyroiditis. Am J Surg Pathol 1989;13:71-7.

8. Simpson NE, Kidd KK, Goodfellow PJ, McDermid H, Myers S, Kidd JR, et al. Assignment of multiple endocrine neoplasia type 2A to chromosome 10 by linkage. Nature 1987;328:528-30.

9. Goodfellow PJ. Mapping, the inherited defects associated with multiple endocrine neoplasia type $2 \mathrm{~A}$, multiple endocrine neoplasia type $2 \mathrm{~B}$, and familial medullary thyroid carcinoma to chromosome 10 by linkage analysis. Endocrinol Metab Clin North Am 1994;23:177-85.

10. Carson NL, Wu J, Jackson CE, Kidd KK, Simpson NE. The mutation for medullary thyroid carcinoma with parathyroid tumors (mTC with PTs) is closely linked to the centromeric region of chromosome 10. Am J Hum Genet 1990;47:946-51.

11. Nelkin BD, Nakamura Y, White RW, de Bustros AC, Herman $\mathrm{J}$, Wells SA, et al. Low incidence of loss of chromosome 10 in sporadic and hereditary human medullary thyroid carcinoma. Cancer Res 1989;49:4114-9.

12. Takahashi M, Ritz J, Cooper GM. Activation of a novel human transforming gene, ret, by DNA rearrangement. Cell 1985;42:581-8.

13. Iwamoto T, Taniguchi M, Asai N. cDNA cloning of mouse ret proto-oncogene and its sequence similarity to the cadherin superfamily. Oncogene 1993;8:1087-91.

14. Mulligan LM, Kwok JBJ, Healey CS, Elsdon MJ, Eng C, Gardner E, et al. Germ-line mutations of the RET proto-oncogene in multiple endocrine neoplasia type 2A. Nature 1993;363:458-60.

15. Hofstra RMW, Landsvater RM, Ceccherini I, Stulp RP, Stelwagen $\mathrm{T}$, Luo $\mathrm{Y}$, et al. A mutation in the RET proto-oncogene associated with multiple endocrine neoplasia type 2B and sporadic medullary thyroid carcinoma. Nature 1994;367:375-6.

16. Eng C, Smith DP, Mulligan LM, Nagai MA, Healey CD, Ponder, MA, et al. Point mutation within the tyrosine kinase domain of the RET proto-oncogene in multiple endocrine neoplasia type $2 \mathrm{~B}$ and related sporadic tumours. Hum Mol Genet 1994;3:237-41.

17. Carlson DM, Dou S, Chi D, Scavarda N, Toshima K, Jackson $\mathrm{CE}$, et al. Single missense mutation in the tyrosine kinase catalytic domain of the RET protooncogene is associated with multiple endocrine neoplasia type 2B. Proc Natl Acad Sci USA 1994;91:1579-83.

18. Nakamura $T$, Ishizaka $Y$, Nagao $M$, Hara $M$, Ishikawa $T$. Expression of the ret proto-oncogene product in human normal and neoplastic tissues of neural crest origin. J Pathol 1994;172:255-60.

19. Santoro M, Rosati R, Grieco M, Berlingieri MT, D'Amato GL, de Francisis V, et al. The ret proto-oncogene is consistently 
expressed in human pheochromocytomas and thyroid medullary carcinomas. Oncogene 1990;5:1595-8.

20. Pachnis V, Mankoo B, Constantini F. Expression of the $c$-ret proto-oncogene during mouse embryogenesis. Development 1993;119:1005-17.

21. Schuchardt A, D'Agati V, Larsson-Blomberg L, Costantini F, Pachnis V. Defects in the kidney and enteric nervous system of mice lacking the tyrosine kinase receptor RET. Nature 1993;367:380-3.

22. Romeo G, Ronchetto P, Luo Y, Barone V, Seri M, Ceccherini I, et al. Point mutations affecting the tyrosine kinase domain of the RET proto-oncogene in Hirschsprung's disease. Nature 1994;367:377-8.

23. Edery P, Lyonnet S, Mulligan LM, Pelet A, Dorn E, Abel L, et al. Mutations of the RET proto-oncogene in Hirschsprung's disease. Nature 1994;367:378-80.

24. Trupp M, Arenas E, Fainzible M, Nilsson AS, Sieber BA, Grigoriou M, et al. Functional receptor for GDNF encoded by the c-ret proto-oncogene. Nature 1996;381:785-9.

25. Ourbec P, Marcos-Gutierrez C, Kilkenny C, Grigoriou M, Wartiouwaara K, Servanto P, et al. GDNF signalling through the RET receptor tyrosine kinase. Nature 1996;381:789-93.

26. Jing S, Wen D, Yu Y, Holst PL, Luo Y, Fang M, et al. GDNFinduced activation of the ret protein tyrosine kinase is mediated by GDNFR- $\alpha$, a novel receptor for GDNF. Cell 1996; 85:1113-24.

27. Treanor JJS, Goodman L, De Sauvage F, Stone DM, Poulsen KT, Beck CD, et al. Characterization of a multicomponent receptor for GDNF. Nature 1996;382:80-3.

28. Sanicola M, Hession C, Worley D, Carmillo P, Ehrenfels C, Walush I, et al. Glial cell line-derived neurotrophic factordependent RET activation can be mediated by two different cell-surface accessory proteins. Proc Natl Acad Sci USA 1997; 94:6238-43.

29. Michiels F-M, Chappuis S, Caillou B, Pasini A, Talbot M, Monier R, et al. Development of medullary thyroid carcinoma in transgenic mice expressing the RET protooncogene altered by a multiple endocrine neoplasia type 2A mutation. Proc Natl Acad Sci USA 1997;94:3330-5.

30. Santoro M, Carlomagno F, Romano A, Bottaro DP, Dathan NA, Grieco M, et al. Activation of RET as a dominant transforming gene by germline mutations of MEN2A and MEN2B. Science 1995;267:381-3.

31. Mulligan LM, Eng C, Healey CS, Clayton D, Kwok JB, Gardner E, et al. Specific mutations of the RET proto-oncogene are related to disease phenotype in MEN 2A and FMTC. Nature Genet 1994;6:70-4.

32. Eng C. The ret proto-oncogene in multiple endocrine neoplasia type 2 and Hirschsprung's disease. N Engl J Med 2000;335:943-51.

33. Gestblom C, Sweetser DA, Doggett B, Kapur RP. Sympathoadrenal hyperplasia causes renal malformations in RET ${ }^{\text {MEN2b }}$ transgenic mice. Am J Pathol 1999;155:2167-79.

34. Bocciardi R, Mograbi B, Pasini B, Borcllo MG, Picrotti MA, Bourget I, et al. The multiple endocrine neoplasia type 2B point mutation switches the specifidity of the RET tyrosine kinase towards, cellular substrates that are susceptible to inerract wth Crk and Nck. Oncogene 1997;15:2257-65.

35. Eng C, Mulligan LM, Healey CS, Houghton C, Frilling A, Raue $\mathrm{F}$, et al. Heterogeneous mutation of the RET proto-oncogene in subpopulations of medullary thyroid carcinoma. Cancer Res 1996;56:2167-70.

36. Lips CJM, Landsvater RM, Höppener JWM, Geerdink RA, Beijham G, van Veen JM, et al. Clinical screening as compared with DNA analysis in families with multiple endocrine neoplasia type 2A. N Engl J Med 1994;331:828-35.

37. Marsh DJ, Robinson BG, Andrew S, Richardson AL, Pojer R, Schuitzler $\mathrm{M}$, et al. A rapid screening method for the detection of mutations in the RET proto-oncogene in multiple endocrine neoplasia type 2A and familial medullary thyroid carcinoma families. Genomics 1994;23:477-9.

38. Tsai M-S, Ledger GA, Khosla S, Gharib H, Thibodeau SN. Identification of multiple endocrine neoplasia, type 2 gene carriers using linkage analysis and analysis of the ret protooncogene. J Clin Endocrinol Metab 1994;78:1261-4.

39. Quadro L, Panariello L, Salvatore D, Carlomagno F, Del Prete $\mathrm{M}$, Nunziata $\mathrm{V}$, et al. Frequent RET protooncogene mutations in multiple endocrine neoplasia type 2A. J Clin Endocrinol Metab 1994;79:590-4.

40. Marsh DJ, Robinson BG, Andrew S, Richardson AL, Pojer R, Schuitzler $\mathrm{M}$, et al. A rapid screening method for the detection of mutations in the RET proto-oncogene in multiple endocrine neoplasia type $2 \mathrm{~A}$ and familial medullary thyroid carcinoma families. Genomics 1994;23:477-9.

41. Wells SA, Jr, Chi DD, Toshima K, Dehner LP, Coffi CM, Dowton SB, et al. Predictive DNA testing and prophylactic thyroidectomy in patients at risk for multiple endocrine neoplasia type 2A. Ann Surg 1994;220:237-50.

42. Santoro M, Rosati R, Grieco M, Berlingieri MT, D'Amato GL, de Francisis V, et al. The ret proto-oncogene is consistently expressed in human pheochromocytomas and thyroid medullary carcinomas. Oncogene 1990;5:1595-8.

43. Zedenius J, Larsson C, Bergholm U, Bovee J, Svensson A, Hallengren B, et al. Mutations of codon 918 in the RET proto-oncogene correlate to poor prognosis in sporadic medullary thyroid carcinomas. J Clin Endocrinol Metab 1995;80:3088-90.

44. Fusco A, Grieco M, Santoro M, Berlingieri MT, Pilotti S, Pierotti MA, et al. A new oncogene in human thyroid papillary carcinomas and their lymph-nodal metastases. Nature 1987;328:170-2.

45. Santoro M, Carlomagno F, Hay ID, Herrmann MA, Grieco M, Melillo R, et al. Ret oncogene activation in human thyroid neoplasms is restricted to the papillary cancer subtype. J Clin Invest 1992;89:1517-22.

46. Pierotti MA, Santoro M, Jenkins R, Sozzi G, Bongarzone I, Grieco M, et al. Characterization of an inversion on the long arm of chromosome 10 juxtaposing D10S170 and RET and creating the oncogenic sequence RET/PTC. Proc Natl Acad Sci USA 1992;89:1616-20.

47. Bongarzone I, Monzini N, Borrello MG, Carcano C, Ferraresi G, Arighi E, et al. Molecular characterization of a thyroid tumor-specific transforming sequence formed by the fusion of ret tyrosine kinase and the regulatory $\mathrm{R} 1 \alpha$ of cyclic AMPdependent protein kinase A. Mol Cell Biol 1993;13:358-66.

48. Santoro M, Dathan NA, Berlingieri MT, Bongarzone I, Paulin C, Grieco M, et al. Molecular characterization of RET/PTC3; a novel rearranged version of the RET proto-oncogene in a human thyroid papillary carcinoma. Oncogene 1994;9:509-16.

49. Sozzi G, Bongarzone I, Miozzo M, Borello MG, Blutti MG, Pilotti S, et al. A t $(10 ; 17)$ translocation creates the RET/PTC2 chimeric transforming sequence in papillary thyroid carcinoma. Genes Chrom Cancer 1994;9:244-50.

50. Fugazzola L, Pierotti MA, Vigano E, Pacini F, Vorontsova TV, Bongarzone I. Molecular and biochemical analysis of RET/ PTC4, a novel oncogenic rearrangement between RET and ELE1 genes, in a post-Cherynobyl papillary thyroid cancer. Oncogene 1996;13:1093-7.

51. Klugbauer S, Lengfelder E, Demidchik EP, Rabes HM. High prevalence of RET rearrangement in thyroid tumors of children from Belarus after the Chernobyl reactor accident. Oncogene 1995;11:2459-67.

52. Nishisho I, Rowland JM, Bove KE, Monforte-Munoz H, Fagin JA. Distinct pattern of ret oncogene rearrangements in morphological variants of radiation-induced and sporadic thyroid papillary carcinoma in children. Cancer Res 1997;57:1690-4.

53. Klugbauer S, Lengfelder E, Demidchik EP, Rabes HM. A new form of RET rearrangement in thyroid carcinomas of chil- 
dren after the Chernobyl reactor acident. Oncogene 1996;13: 1099-102.

54. Klugbauer S, Demidchik EP, Lengfelder E, Rabes HM. Detection of a novel type of RET rearrangement (PTC5) in thyroid carcinomas after Chernobyl and analysis of the involved RET-fused gene RFG5. Cancer Res 1998;58:198-203.

55. Nikiforov Y, Koshoffer A, Nikiforova M, Stringer J, Fagin JA. Chromosomal breakpoint positions sugeest a direct role for radiation in inducing illegitimate recombination between the ELE1 and RET genes in radiation-induced thyroid carcinomas. Oncogene 1999;18:6330-4.

56. Williams GH, Rooney S, Thomas GA, Cummins G, Williams ED. RET activation in adult and childhood papillary thyroid carcinoma using a reverse transcriptase-polymerase chain reaction approach on archival-nested material. Br J Cancer 1996;74:585-9.

57. Jhiang SM, Caruso DR, Gilmore E, Ishizaka Y, Tahira T, Nagao M, et al. Detection of the PTC/retTPC oncogene in human thyroid cancers. Oncogene 1992;7:1331-7.

58. Sugg SL, Zheng L, Rosen IB, Freeman JL, Ezzat S, Asa SL. ret/PTC-1,-2 and -3 oncogene rearrangements in human thyroid carcinomas: Implications for metastatic potential? J Clin Endocrinol Metab 1996;81:3360-5.

59. Mayr B, Brabant G, Goretzki P, Ruschoff J, Dietmaier W, Dralle $\mathrm{H}$. ret/Ptc-1, -2 , and -3 oncogene rearrangements in human thyroid carcinomas: implications for metastatic potential [letter; comment]? J Clin Endocrinol Metab 1997;82:1306-7.

60. Jhiang SM, Sagartz JE, Tong Q, Parker-Thornburg J, Capen CC, Cho JY, et al. Targeted expression of the ret/PTC1 oncogene induces papillary thyroid carcinomas. Endocrinology 1996;137:375-8.

61. Santoro M, Chiappetta G, Cerato A, Salvatore D, Zhang L, Manzo G, et al. Development of thyroid papillary carcinomas secondary to tissue-specific expression of the RET/PTC1 oncogene in transgenic mice. Oncogene 1996;12:1821-6.

62. Powell DJ Jr, Russel J, Nibu K, Li G, Rhee E, Liao M, et al. The RET/PTC3 oncogene: metastatic solid-type papillary carcinomas in murine thyroids. Cancer Res 1998;58:5523-8.

63. Ishizaka Y, Shima H, Sugimura T, Nagao M. Detection of phosphorylated ret/TPC oncogene product in cytoplasm. Oncogene 1992;7:1441-4.

64. Tong Q, Xing S, Jhiang S. Leucine zipper-mediated dimerization is essential for the PTC1 oncogenic activity. J Biol Chem 1997;272:9043-7.

65. De Vita G, Zannini M, Cirafici AM, Melillo RM, Di Lauro R, Fusco A, et al. Expression of the RET/PTC1 oncogene impairs the activity of TTF-1 and Pax-8 transcription factors. Cell Growth Differ 1998;9:97-103.

66. Fischer AH, Bond JA, Taysavang P, Battles OE, WynfordThomas D. Papillary thyroid carcinoma oncogene (RET/ PTC) alters the nuclear envelope and chromatin structure. Am J Pathol 1998;153:1443-50.

67. Durick K, Wu R-Y, Gill GN, Taylor SS. Mitogenic signaling by Ret/ptc2 requires association with enigma via a LIM domain. J Biol Chem 1996;271:12691-4.

68. Viglietto G, Chiappetta G, Martinez-Tello FJ, Fukunaga FH, Tallini G, Rigopoulou D, et al. RET/PTC oncogene activation is an early event in thyroid carcinogenesis. Oncogene 1995; 11:1207-10.

69. Sugg SL, Ezzat S, Rosen IB, Freeman J, Asa SL. Distinct multiple ret/PTC gene rearrangements in multifocal papillary thyroid neoplasia. J Clin Endocrinol Metab 1998;83:4116-22.

70. Thomas GA, Bunnell H, Cook HA, Williams ED, Nerovnya A, Cherstvoy ED, et al. High prevalence of RET/PTC rearrangements in Ukrainian and Belarussian post-Chernobyl thyroid papillary carcinomas: a strong correlation between RET/
PTC3 and the solid-follicular variant. J Clin Endocrinol Metab 1999;84:4232-8.

71. Nikiforov YE, Rowland JM, Bove KE, Monforte-Munoz H, Fagin JA. Distinct pattern of ret oncogene rearrangements in morphological variants of radiation-induced and sporadic thyroid papillary carcinomas in children. Cancer Res 1997; 57:1690-4.

72. Soares P, Fonseca E, Wynford-Thomas D, Sobrinho-Simoes M. Sporadic ret-rearranged papillary carcinoma of thyroid: a subset of slow growing, less aggressive thyroid neoplasms? J Pathol 2000;185:71-8.

73. Tallini G, Santoro M, Helie M, Carlomango F, Salvatore G, Chiappetta G, et al. RET/PTC oncogene activation defines a subset of papillary thyroid carcinomas lacking evidence of progression to poorly differentiated or undifferentiated tumor phenotypes. Clin Cancer Res 1998;4:287-94.

74. Wirtschafter A, Schmidt R, Rosen D, Kundu N, Santoro M, Fusco A, et al. Expression of the RET/PTC fusion gene as a marker for papillary carcinoma in Hashimoto's thyroiditis. Laryngoscope 1997;107:95-100.

75. Fink A, Tomlinson G, Freeman JL, Rosen IB, Asa SL. Occult micropapillary carcinoma associated with benign follicular thyroid disease and unrelated thyroid neoplasms. Mod Pathol 1996;9:816-20.

76. Rosai J, Carcangiu ML, DeLellis RA. Tumors of the thyroid gland. Atlas of tumor pathology. Third Series, Fascicle 5. Washington, DC: Armed Forces Institute of Pathology; 1992.

77. LiVolsi VA. Surgical pathology of the thyroid. Philadelphia: W.B. Saunders; 1990.

78. Hedinger C, Williams ED, Sobin LH. The WHO histological classification of thyroid tumors: a commentary on the second edition. Cancer 1989;63:908-11.

79. Thompson NW, Dunn EL, Batsakis JG, Nishiyama RH. Hürthle cell lesions of the thyroid gland. Surg Gynecol Obstet 1974;139:555-60.

80. Herrera MF, Hay ID, Wu PS, Groellner JR, Ryan JJ, Ebersold JR, et al. Hürthle cell (oxyphilic) papillary thyroid carcinoma: a variant with more aggressive biologic behavior. World J Surg 1992;16:669-75.

81. Dickersin GR, Vickery AL, Smith SB. Papillary carcinoma of the thyroid, oxyphil cell type, "clear cell" variant. A light and electron microscopic study. Am J Surg Pathol 1980;4:501-9.

82. Bronner MP, LiVolsi VA. Oxyphilic (Askenasy/Hürthle cell) tumors of the thyroid. Microscopic features predict biologic behavior. Surg Pathol 1988;1:137-50.

83. Hill JH, Werkhaven JA, DeMay RM. Hürthle cell variant of papillary carcinoma of the thyroid gland. Otolaryngol Head Neck Surg 1988;98:338-41.

84. Apel RL, Asa SL, LiVolsi VA. Papillary Hürthle cell carcinoma with lymphocytic stroma. "Warthin-like tumor" of the thyroid. Am J Surg Pathol 1995;19:810-14.

85. Beckner ME, Heffess CS, Oertel JE. Oxyphilic papillary thyroid carcinoma. Am J Clin Pathol 1995;103:280-7.

86. Cheung CC, Ezzat S, Ramyar L, Freeman J, Asa SL. Molecular basis of Hurthle cell papillary thyroid carcinoma. J Clin Endocrinol Metab 2000;85:878-82.

87. Papotti M, Volante M, Guiliano A, Fassina A, Fusco A, Bussolati G, et al. RET/PTC activation in hyalinizing trabecular tumors of the thyroid. Am J Surg Pathol 2000;24:1615-21.

88. Cheung CC, Boerner SL, MacMillan CM, Ramyar L, Asa SL. Hyalinizing trabecular tumor of the thyroid: a variant of papillary carcinoma proved by molecular genetics. Am J Surg Pathol 2000;24:1622-6.

89. Cheung CC, Cardis B, Ezzat S, Bedard YC, Asa SL. Molecular genetic analysis refines the fine needle aspiration diagnosis of thyroid cancer. J Clin Endocrinol Metab (in press). 